\title{
Effect of tooth spacing and mesh size on the catch of the Portuguese clam and razor clam dredge
}

\author{
M. B. Gaspar, M. Castro, and C. C. Monteiro
}

Gaspar, M. B., Castro, M., and Monteiro, C. C. 1999. Effect of tooth spacing and mesh size on the catch of the Portuguese clam and razor clam dredge. - ICES Journal of Marine Science, 56: 103-110.

\begin{abstract}
Experiments on the selectivity of the clam and razor clam dredges were carried out during July 1995, on the south coast of Portugal. The effects of mesh size and tooth spacing were investigated for both the clam and razor clam dredges. Four different mesh sizes $(25,35,40$, and $50 \mathrm{~mm})$ and three different tooth spacings $(15,20$, and $25 \mathrm{~mm}$ for the clams Spisula solida and Venus striatula, and 10, 15, and $20 \mathrm{~mm}$ for the razor clam Ensis siliqua) were used. The results indicated that the tooth spacing did not have an effect on the selectivity. The best mesh sizes were $40 \mathrm{~mm}$ for the clam fishery ( $S$. solida and $V$. striatula) and 66 for the razor clam (E. siliqua). These mesh sizes will result in considerable reduction in the numbers of small- and medium-sized individuals in the catch.
\end{abstract}

(C) 1999 International Council for the Exploration of the Sea

Key words: dredge, selectivity, bivalve, Ensis siliqua, Venus striatula, Spisula solida.

Received 2 March 1998; accepted 2 September 1998.

M. B. Gaspar and C. C. Monteiro: Instituto de Investigação das Pescas e do Mar, Centro Regional de Investigação Pesqueira do Sul, Avenida 5 de Outubro s/n, 8700 Olhão, Portugal. M. Castro: Universidade do Algarve, Unidade de Ciências e Tecnologias dos Recursos Aquáticos, Campus de Gambelas, 8000 Faro, Portugal. Correspondence to M. B. Gaspar: tel: +351 89700 503; fax: + 35189700 535; email: mbgaspar@valg.pt

\section{Introduction}

An important bivalve fishery takes place along the south coast of Portugal. Among the Portuguese, bivalve fishing is an ancient and traditional activity. Until the 1960s the harvesting of bivalves was restricted to estuaries and lagoons. In ancient times bivalves were harvested by hand or by hand rakes at low tide. At the beginning of the twentieth century, small dredges were introduced to the fishery. The dredges were very similar to those used nowadays but smaller and with a bag made of leather (Ruano, 1997). The gear was towed from rowboats with a cable or with a long-handled pole (Silva, 1893). The exploitation of bivalve ocean beds along the Portuguese coast is recent and was initiated in 1969 by the Spanish fleet under the auspices of the "Portuguese-Spanish Fishery Agreement". The Spanish fleet directed its fishing effort mainly towards two species Ensis siliqua and Venus striatula. The high economic value of these species in the external market soon aroused great interest in the Portuguese fleet. Thus, the fishing effort as well as the gear efficiency increased and as a consequence bivalve beds soon showed signs of depletion. By that time
Instituto de Investigação das Pescas e do Mar (IPIMAR) had started a research programme in order to study the distribution, biology, and ecology of the species.

Unfortunately no reliable statistical data are available since, until 1997, fishermen were not obliged to declare their catches. However, the last bivalve survey carried out by IPIMAR showed that bivalve beds were overexploited. Thus, it is important to introduce or modify some management measures in order to overcome the present situation.

At present the most important commercial species are the clams Spisula solida and Venus striatula, and the razor clam Ensis siliqua. All three species inhabit sand bottoms at depths between 3 and $12 \mathrm{~m}$ where they form extensive and dense beds, sometimes strips that reach several miles. These populations constitute the target of a specific fishing activity carried out by an artisanal fleet. The boats involved in the fishery are $4-15 \mathrm{~m}$ long, with engines of $17-150 \mathrm{hp}$ and a crew of 1-5 fishermen. Dredges are the gear used in this fishery.

The basic structure of the Portuguese clam and razor dredge is a small, heavy semicircular iron structure, with 


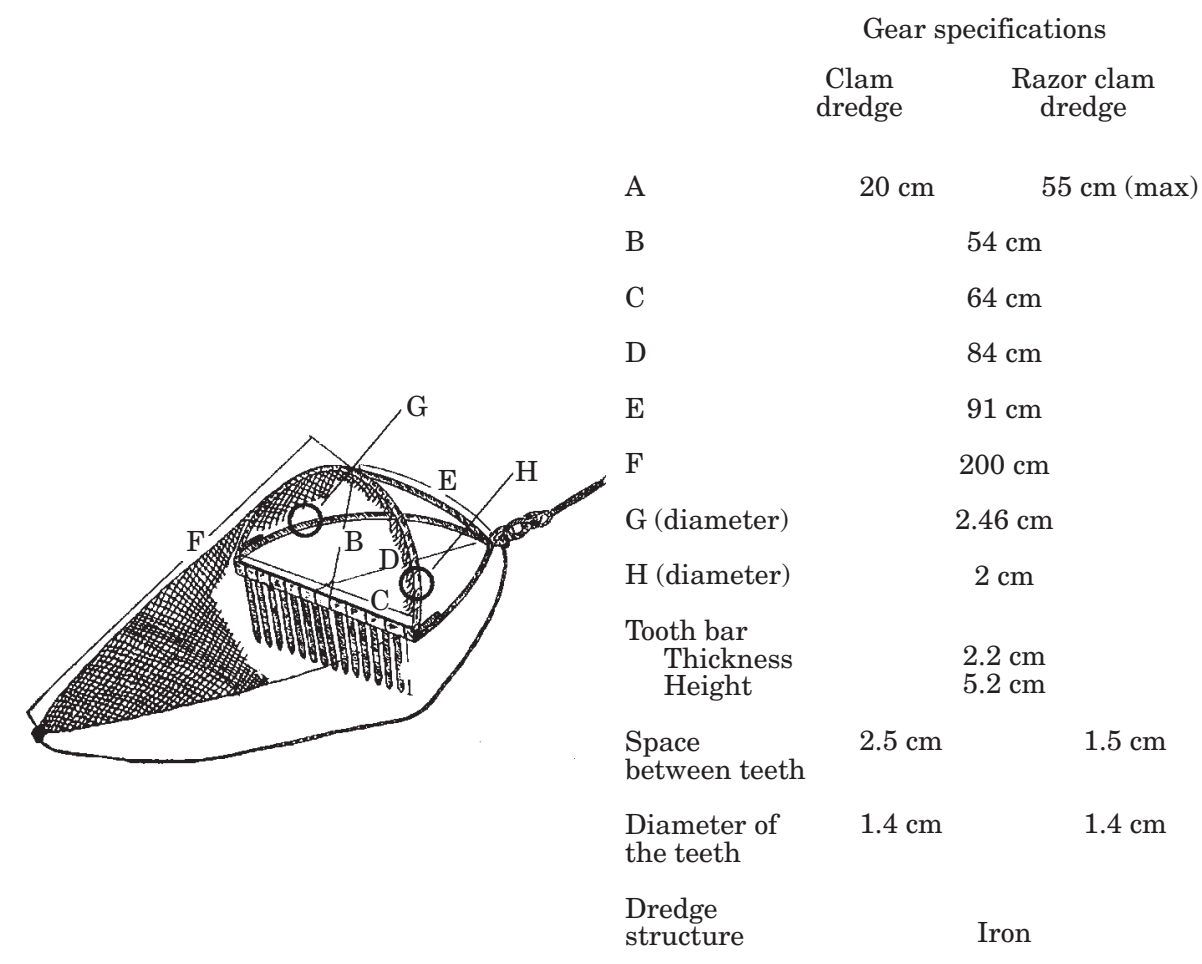

Figure 1. Diagram of a Portuguese dredge and its specifications (adapted from Monteiro, 1985).

a net bag and a toothed lower bar at the mouth. The lower bar has 12-14 teeth with a maximum length of $55 \mathrm{~cm}$ spaced $1.5-2.5 \mathrm{~cm}$ apart, acting as the lower leading edge of the dredge. Welded to this iron structure are three metal shafts forming a kind of hen's foot where the towing cable is attached (Fig. 1).

Large yearly fluctuations in the recruitment of these species are observed (Gaspar, 1996). In such resources the classical approach of maximizing yield-per-recruit is less important than conserving the spawning stock at densities that allow these species to take advantage of future favourable environmental conditions (Caddy, 1989). With this objective, several management measures were applied to this fishery. These measures included minimum legal landing length (MLL) and minimum mesh size (MMS). A MLL of $25 \mathrm{~mm}$ for $S$. solida and $V$. striatula, and $100 \mathrm{~mm}$ for $E$. siliqua was introduced to allow spawning at least once before capture. Minimum legal banding lengths were based on the size/age of first maturity, life span, and growth of the species (Gaspar et al., 1994, 1995; Gaspar, 1996). Nevertheless, the capture of undersized individuals is still a great problem. There are high discard rates in this fishery because adults and juveniles are found in the same areas.

The mortality due to fishing is affected by the survival rates of discarded individuals. Recently Gaspar and Monteiro (unpubl.) showed that undamaged juveniles of
S. solida are extremely sensitive to the time of exposure on the deck. These authors estimated a fishing mortality rate of $0.003 \mathrm{~min}^{-1}$ out of water. As catches are usually sorted at the end of the trip, mortality is high. This is a problem of particular importance during summer, when high temperatures increase mortality and densities of undersized individuals are higher. A good management option would be to avoid a large by-catch of undersized clams and razor clams in the first place.

According to Drinkwater (1974), mesh size and tooth spacing are the most important dredge features that affect selectivity. The effect of these two characteristics was studied with the objective of quantifying the catch of undersized individuals retained and estimating a minimum mesh size.

\section{Methods}

\section{Experimental design}

The selectivity experiments were conducted during groundfish surveys, off the south coast of Portugal, carried out on board the "NI DONAX" in July 1995. The vessel is of similar size and power of the commercial ones as well as the dredges used. For experimental purposes the dredges were fitted with interchangeable tooth bars. The specifications of the gear used in the experiment are summarized in Figure 1. 
Four different mesh sizes 25, 35, 40, and $50 \mathrm{~mm}$ were investigated. These sizes were chosen to cover a range of mesh sizes and include the one in current use $(25 \mathrm{~mm})$. All meshes were measured across the diagonal of fully stretched nets. Three different tooth spacings were used: 15 , 20 , and $25 \mathrm{~mm}$ for $S$. solida and V. striatula; and 10, 15, and $20 \mathrm{~mm}$ for $E$. siliqua. These sizes included tooth spacing in current use and narrower and wider spacings for comparison. For each gear combination (teeth and mesh size) 10 hauls were made. This gave a total of 240 hauls, 120 hauls for S. solida and V. striatula, and 120 hauls for E. siliqua.

The dredge selectivity experiments were conducted by attaching to the gear a cover bag with a $20 \mathrm{~mm}$ mesh. This bag was 1.6 times longer and wider than the primary net bag and did not impede the natural flow of water through the net. Two dredges with equal teeth and different bag meshes were towed side by side. All fishing hauls were conducted at a towing speed of $1-1.5$ knots at depths between 5 and $10 \mathrm{~m}$ with duration of $3 \mathrm{~min}$. After each haul the catches in the bag and in the cover were sorted separately. For all species the standard length was measured to the millimetre and subsequently grouped into $2 \mathrm{~mm}$ classes, in the case of $V$. striatula and $S$. solida, and into $5 \mathrm{~mm}$ classes in the case of E. siliqua.

\section{Data analysis}

It was assumed that the selection curves followed a logistic model, which is expressed by the following equation (Paloheimo and Cadima, 1964):

$\mathrm{P}(\mathrm{L})=\frac{1}{1+\exp ^{-(\mathbf{a}+\mathrm{b} \mathbf{L})}}$

Where: $\mathrm{L}$ is the centre of the length class; $\mathrm{P}(\mathrm{L})$ is the retention proportion for length cases $\mathrm{L}$; and $\mathrm{a}$ and $\mathrm{b}$ are parameters.

The logistic curves were fitted using non-linear regression with the routine PROC NLIN, part of the statistical package SAS (SAS Institute Inc., 1989). This iteractive curve fitting procedure employs a non-linear leastsquare regression method (Gauss-Newton) and estimates $\mathrm{a}$ and $\mathrm{b}$ from the above equation. Useful parameters of a selection curve are $\mathrm{L}_{50 \%}$ (theoretical length at which $50 \%$ of the individuals are retained) and the selection range, SR (difference between $\mathrm{L}_{75 \%}$ and $\mathrm{L}_{25 \%}$ ). These two parameters are related to the parameters of the logistic equation by the expressions:

$\mathrm{L}_{50 \%}=-\frac{\mathrm{a}}{\mathrm{b}}$

and:

$\mathrm{SR}=2 \times \frac{\ln 3}{\mathrm{~b}}$

To compare the selection curves, the vectors of estimated parameters were tested for equality using the multivariate Hotelling's $\mathrm{T}^{2}$-test (Bernard, 1981; Hanumara and Hoenig, 1987). It was assumed that the distribution of the estimated parameters was normal (Morrison, 1976). This $\mathrm{T}^{2}$ statistic was used to test the null hypothesis $\mathrm{H}_{0}: \mathrm{P}_{1}=\mathrm{P}_{2}$ vs. $\mathrm{H}_{\mathrm{a}}: \mathrm{P}_{1} \neq \mathrm{P}_{2}$ where $\mathrm{P}_{1}$ and $\mathrm{P}_{2}$ are the parameter vectors for both selectivity curves. $\mathrm{T}^{2}$ has a modified F-distribution (Bernard, 1981). The variance-covariance matrices, necessary for the calculation of $\mathrm{T}^{2}$, were resulted from the iteractive procedure with convergence, part of the non-linear fit. According to Hanumara and Hoenig (1987) these matrices can be used in the test, as an approximation of true variancecovariance matrices, without the introduction of significant error or bias. The statistic of the test $\left(\mathrm{T}^{2}\right)$ is compared with the modified F-values $\left(\mathrm{T}^{0}\right)$. The null hypothesis is rejected whenever $\mathrm{T}^{2}>\mathrm{T}^{0}$.

\section{Results}

The effect of tooth spacing on the selectivity of the dredges was analysed first. In these experiments mesh size was ignored and catches in the bag and cover were added together for hauls with the same tooth spacing. The length distributions of the catch, for each of the species studied, are represented in Figure 2.

If tooth spacing had a selective effect in the size range caught, the length frequencies obtained for each tooth spacing would be different. One would expect that narrower tooth spacing would correspond to length distributions with a higher proportion of smaller individuals. This hypothesis was not confirmed, and in one of the species, S. solida, the opposite was found, the wider tooth spacing corresponded to higher proportion of small individuals. These results led to the conclusion that tooth spacing, within the ranges studied here, does not affect the selectivity of the dredge.

After establishing that tooth spacing was of no importance for the selectivity of these dredges, the effect of mesh size was studied ignoring this factor, that is, data from the hauls with the same mesh size were pooled, ignoring the tooth spacing used. Figure 3 shows the estimated selectivity curves for $S$. solida, $V$. striatula, and E. siliqua, respectively. Table 1 summarizes the parameters obtained for the three species studied, and Figure 4 shows the length distributions for different mesh sizes and species.

The Hotelling's $\mathrm{T}^{2}$-test was applied to pairs of curves of the same species corresponding to different mesh sizes. The results of the test as well as the values limiting the rejection area for $\alpha=0.01$ are presented in Table 2 .

The $50 \%$ retention lengths for mesh sizes $25,35,40$, and $50 \mathrm{~mm}$ and for the species S. solida are 13.9, 16.6, 20.5 , and $23.3 \mathrm{~mm}$, respectively. All these values are below the $25 \mathrm{~mm}$ MLL for this species. However, the selection range for the 40 and 50 meshes includes the 

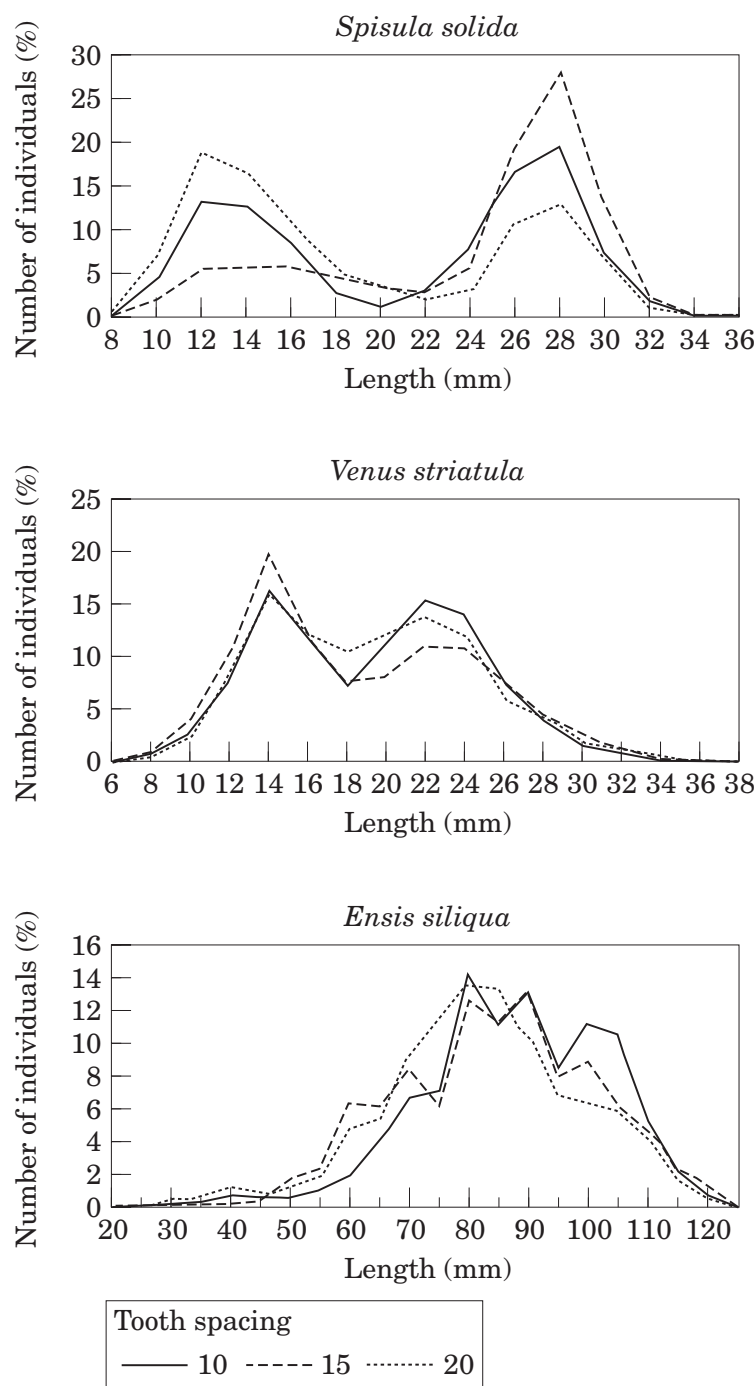

Figure 2. Length frequency distributions by tooth spacing obtained for all experiments and for the three species studied.

MLL. For the $35 \mathrm{~mm}$ mesh, the MLL was very close to $\mathrm{L}_{75 \%}$. The selection range for this mesh is very wide, which leads to the capture of a high proportion of undersized individuals. The $50 \%$ retention lengths for $V$. striatula were $14.0,18.8,18.0$, and $21.4 \mathrm{~mm}$, for mesh sizes $25,35,40$, and 50 , respectively. Only the selection range estimated for mesh size 50 includes the MLL for this species, which is also $25 \mathrm{~mm}$.

The $50 \%$ retention lengths for E. siliqua were 39.3, $57.2,61.9$, and $65.4 \mathrm{~mm}$, for mesh sizes $25,35,40$, and $50 \mathrm{~mm}$, respectively. All these values are considerably below the MLL for this species, which is $100 \mathrm{~mm}$.

\section{Discussion}

Management of these species usually combines a minimum legal landing length (MLL) with a minimum mesh size (MMS). The objective is to aid enforcement by discouraging fishermen from using very small meshes that lead to the rejection of a large proportion of the catch. For the present study, a $50 \%$ selection length of approximately $25 \mathrm{~mm}$ was the target for the clam dredge because this value is the current minimum landing size for $S$. solida and $V$. striatula. Similarly, for the razor clam dredge, our target was a $50 \%$ selection length of $100 \mathrm{~mm}$, the minimum legal length for E. siliqua.

Data from the present study suggests that the estimated $\mathrm{L}_{50 \%}$ values are markedly below the stipulated MLL for $S$. solida and $V$. striatula. As both species are caught together, the mesh size recommended will be a compromise between the two species. Figure 5 shows the observed proportion of retention of individuals with lengths below and above the MLL. The effect of mesh sizes on the catches is clear for S. solida; the retained proportion of undersized clams decreasing with the increasing mesh. The same pattern was not seen for $V$. striatula, for example the mesh size of $40 \mathrm{~mm}$ caught more undersized clams than the $35 \mathrm{~mm}$ mesh size. This can be explained because, at the larger mesh size the bag became blocked by $S$. solida decreasing the escapement of $V$. striatula. The present experiments suggest that the $40 \mathrm{~mm}$ mesh size would be a reasonable compromise. This mesh size retains a high proportion of adult individuals as well as allowing the escapement of a high percentage of undersized clams.

One aspect of the selectivity parameters estimated is the wide selection range for all species studied. This may be related with the way the gear is operated, as observed by divers during the experimental phase of this work. While the dredge in being towed, there is very little escapement from the bag into the cover, because the mesh closes as it is stretched. It is when the dredge is hauled vertically and washed that most of the escapement through the bag occurs. In such a situation the escapement affects individuals of a wide length range, in particular for the species E. siliqua, the razor clam. For this species, the selectivity parameters are largely the result of the morphology of the shell. In fact, adult razor clams rapidly block the meshes and make selection ineffective. Therefore a larger number of undersized individuals are caught. As a consequence, the values of both $\mathrm{L}_{50 \%}$ and selection range are the largest of the three species. The mesh to be adopted for the Ensis fishery should be different from that used for the other two clams. A $40 \mathrm{~mm}$ mesh and its corresponding $\mathrm{L}_{50 \%}$ of $61.9 \mathrm{~mm}$ is markedly below the stipulated MLL for the species. Assuming the selection factor is more or less constant for a given gear and species, and is approximately equal to the ratio $\mathrm{L}_{50 \%} / \mathrm{mesh} \_$size, the indicated mesh, chosen to obtain a $\mathrm{L}_{50 \%}$ close to $100 \mathrm{~mm}$, would be $66 \mathrm{~mm}$. If experimental observations confirm this hypothesis, the adoption of a different pattern of exploitation would be justified also because this species does 
Spisula solida
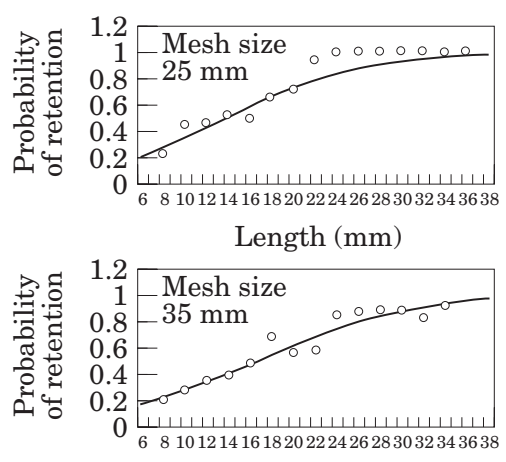

Length (mm)

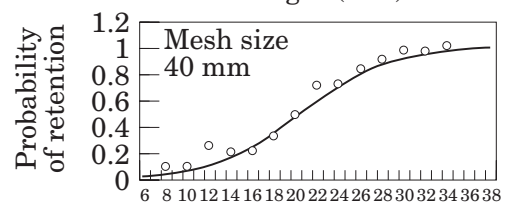

Length (mm)

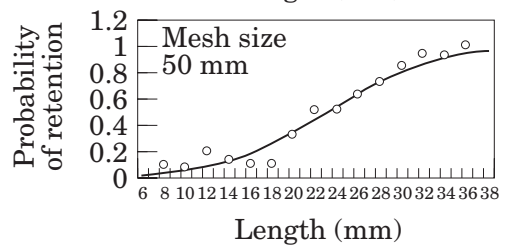

Venus striatula

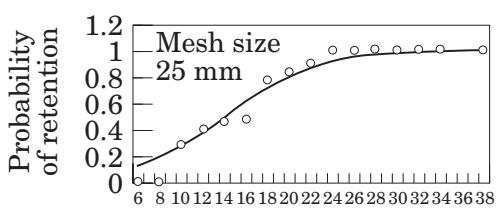

Length (mm)

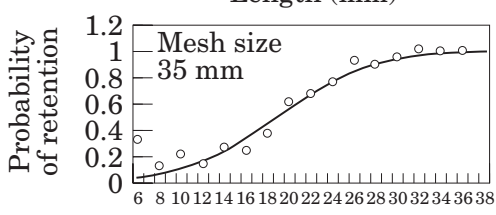

Length (mm)

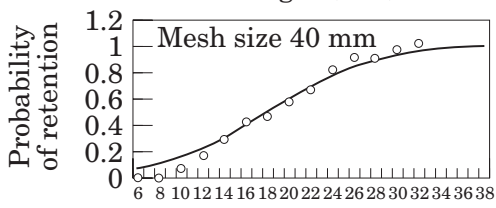

Length (mm)

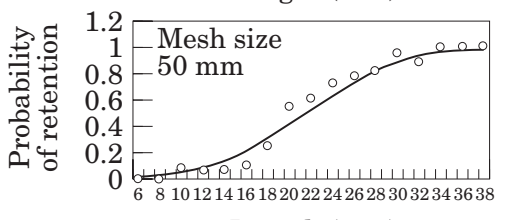

Length (mm)
Ensis siliqua

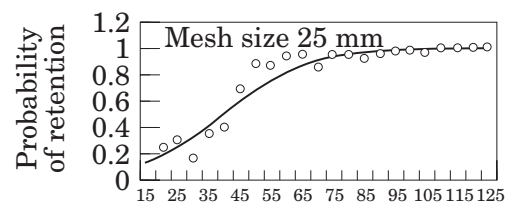

Length ( $\mathrm{mm}$ )

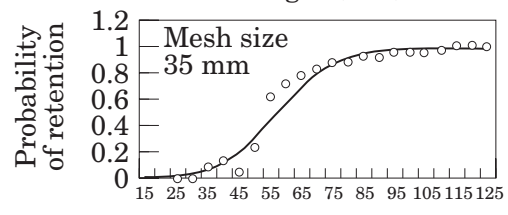

Length ( $\mathrm{mm})$

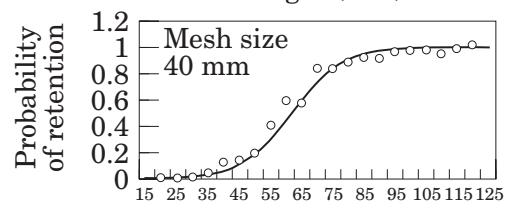

Length ( $\mathrm{mm})$

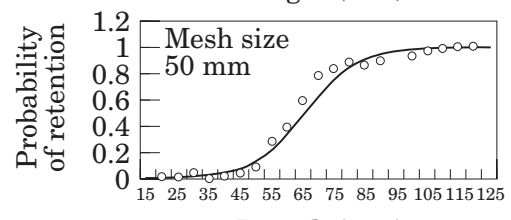

Length (mm)

Figure 3. Selectivity curves estimated for Spisula solida, Venus striatula, and Ensis siliqua. The vertical line represents the minimum legal landing length (MLL) of this species. The horizontal line represents $\mathrm{L}_{50 \%}$.

Table 1. Selectivity parameters for the three species studies where: $\mathrm{a}$ and $\mathrm{b}$ are the parameters of the logistic curve, $\mathrm{r}$ is the coefficient of determination, $\mathrm{L}_{50 \%}, \mathrm{~L}_{75 \%}$, and $\mathrm{L}_{25 \%}$ are the lengths at which $50 \%$, $75 \%$, and $25 \%$ of the individuals are retained, $\mathrm{SR}$ is the selection range $\left(\mathrm{L}_{75 \%}-\mathrm{L}_{25 \%}\right)$, and $\mathrm{SF}$ is the selection factor $\left(\mathrm{L}_{50 \%} / \mathrm{mesh}_{\text {size }}\right)$.

\begin{tabular}{|c|c|c|c|c|c|c|c|c|}
\hline Mesh & $\mathrm{a}$ & $\mathrm{b}$ & $\mathrm{r}$ & $\mathrm{L}_{25 \%}$ & $\mathrm{~L}_{50 \%}$ & $\mathrm{~L}_{75 \%}$ & SR & SF \\
\hline \multicolumn{9}{|c|}{ Spisula solida } \\
\hline $25 \mathrm{~mm}$ & -2.215 & 0.156 & 0.941 & 7.0 & 13.9 & 20.7 & 13.7 & 0.6 \\
\hline $35 \mathrm{~mm}$ & -2.351 & 0.142 & 0.956 & 8.8 & 16.6 & 24.3 & 15.5 & 0.5 \\
\hline $40 \mathrm{~mm}$ & -5.003 & 0.244 & 0.948 & 16.0 & 20.5 & 25.0 & 9.0 & 0.5 \\
\hline $50 \mathrm{~mm}$ & -4.771 & 0.205 & 0.978 & 17.9 & 23.3 & 28.7 & 10.7 & 0.5 \\
\hline \multicolumn{9}{|c|}{ Venus striatula } \\
\hline $25 \mathrm{~mm}$ & -3.275 & 0.234 & 0.869 & 9.3 & 14.0 & 18.7 & 9.4 & 0.6 \\
\hline $35 \mathrm{~mm}$ & -4.285 & 0.228 & 0.964 & 14.0 & 18.8 & 23.6 & 9.3 & 0.5 \\
\hline $40 \mathrm{~mm}$ & -3.641 & 0.202 & 0.988 & 12.6 & 18.0 & 23.5 & 10.9 & 0.5 \\
\hline $50 \mathrm{~mm}$ & -4.908 & 0.229 & 0.987 & 16.6 & 21.4 & 26.2 & 9.6 & 0.4 \\
\hline \multicolumn{9}{|c|}{ Ensis siliqua } \\
\hline $25 \mathrm{~mm}$ & -2.289 & 0.074 & 0.962 & 24.3 & 39.3 & 54.2 & 29.9 & 1.6 \\
\hline $35 \mathrm{~mm}$ & -6.144 & 0.107 & 0.987 & 47.0 & 57.2 & 67.5 & 20.5 & 1.6 \\
\hline $40 \mathrm{~mm}$ & -7.780 & 0.126 & 0.991 & 53.2 & 61.9 & 70.6 & 17.5 & 1.6 \\
\hline $50 \mathrm{~mm}$ & -7.780 & 0.119 & 0.996 & 56.1 & 65.4 & 74.5 & 18.5 & 1.3 \\
\hline
\end{tabular}

not coexist with the other two species which were studied.

Several factors have been known to affect dredge selectivity. These factors include the nature of the bottom, the duration of the tow and the design of the dredge. Drinkwater (1974) stressed the importance of the nature of the bottom in the scallop fishery. This author reported that the dredge is likely to bounce in 
Spisula solida
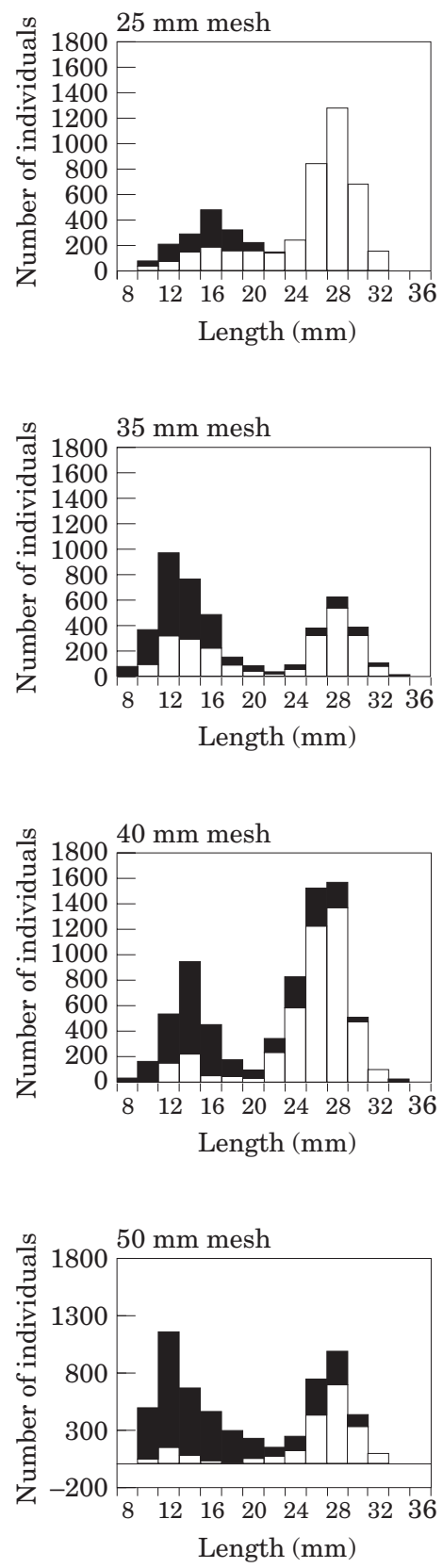

Venus striatula
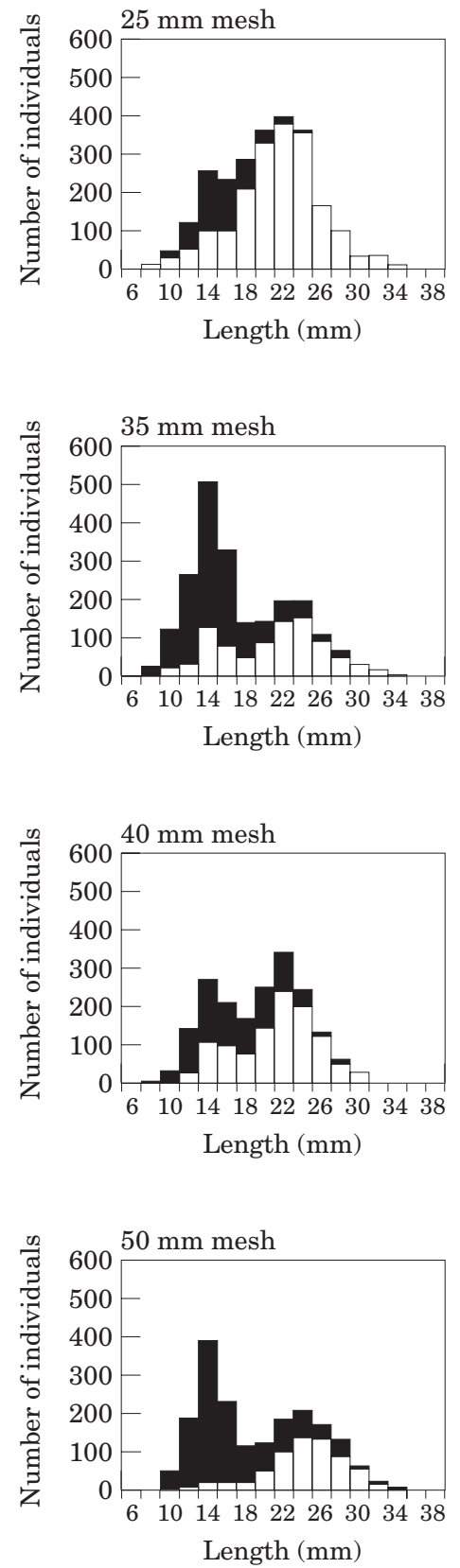

Ensis siliqua
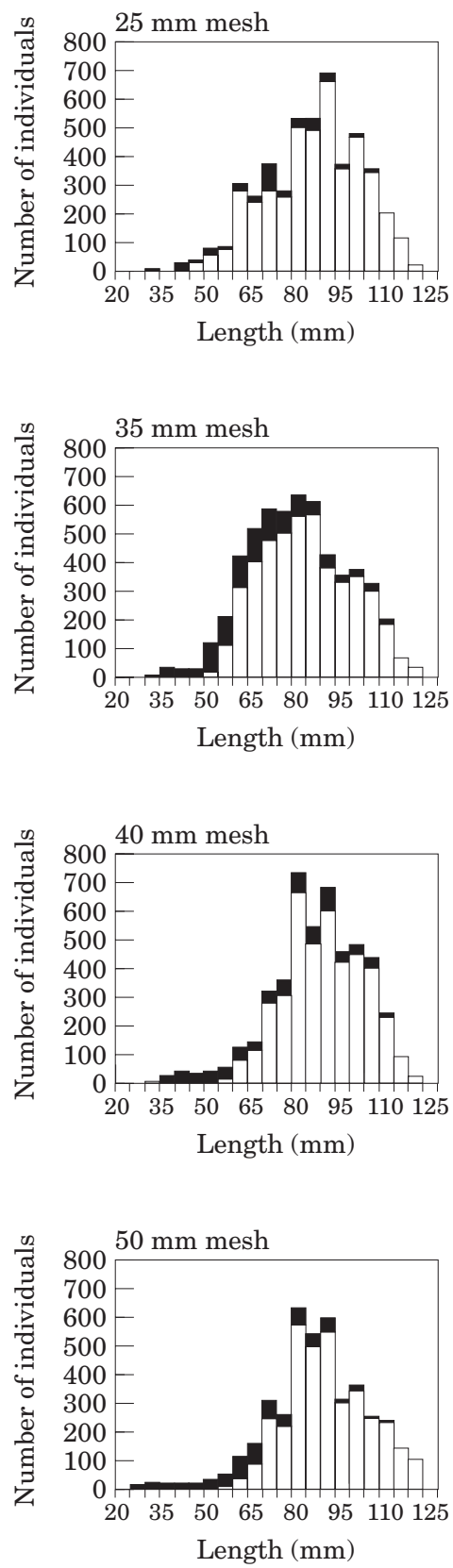

\section{Cover $\square$ Bag}

Figure 4. Length frequency distributions by mesh size obtained for all experiments and for the three species studied.

some places and fill with mud and stones in others. Thus selectivity will depend partially on the nature of the bottom deposits scraped up by the dredge. In the Portuguese dredge fishery, the nature of the bottom does not constitute a problem, since the exploited species only forms extensive and dense beds on very clean sandy bottoms (Gaspar, 1996).

The second factor affecting selectivity reported by Drinkwater (1974), was the duration of the tow, which was not studied in the present work. However, the 
Table 2. Results of the Hotteling's $\mathrm{T}^{2}$-test, where $\mathrm{T}^{0}$ is the modified F-statistic value limiting the rejection area for $\alpha=0.01$. The null hypothesis $H_{0}: P_{1}=P_{2}\left(\right.$ vs. $\left.H_{a}: P_{1} \neq P_{2}\right)$ is rejected when $T^{2}>T^{0}$.

\begin{tabular}{|c|c|c|c|c|}
\hline & Mesh & $35 \mathrm{~mm}$ & $40 \mathrm{~mm}$ & $50 \mathrm{~mm}$ \\
\hline Venus striatula & $\begin{array}{l}25 \mathrm{~mm} \\
35 \mathrm{~mm} \\
40 \mathrm{~mm}\end{array}$ & $\begin{array}{c}\mathrm{T}^{2}=701.53 \\
\mathrm{~T}_{0}=10.32 \\
\mathrm{H}_{0} \text { Rejected }\end{array}$ & $\begin{array}{c}\mathrm{T}^{2}=395.21 \\
\mathrm{~T}_{0}=10.66 \\
\mathrm{H}_{0} \text { Rejected } \\
\mathrm{T}^{2}=51.91 \\
\mathrm{~T}_{0}=10.27 \\
\mathrm{H}_{0} \text { Rejected }\end{array}$ & $\begin{array}{c}\mathrm{T}^{2}=1618.96 \\
\mathrm{~T}_{0}=10.12 \\
\mathrm{H}_{0} \text { Rejected } \\
\mathrm{T}^{2}=1968.37 \\
\mathrm{~T}_{0}=9.91 \\
\mathrm{H}_{0} \text { Rejected } \\
\mathrm{T}^{2}=358.74 \\
\mathrm{~T}_{0}=9.98 \\
\mathrm{H}_{0} \text { Rejected } \\
\mathrm{T}^{2}=930.07 \\
\mathrm{~T}_{0}=10.36 \\
\mathrm{H}_{0} \text { Rejected } \\
\mathrm{T}^{2}=362.97 \\
\mathrm{~T}_{0}=10.11 \\
\mathrm{H}_{0} \text { Rejected } \\
\mathrm{T}^{2}=476.01 \\
\mathrm{~T}_{0}=10.32 \\
\mathrm{H}_{0} \text { Rejected } \\
\mathrm{T}^{2}=1980.12 \\
\mathrm{~T}_{0}=10.00 \\
\mathrm{H}_{0} \text { Rejected } \\
\mathrm{T}^{2}=557.40 \\
\mathrm{~T}_{0}=9.91 \\
\mathrm{H}_{0} \text { Rejected } \\
\mathrm{T}^{2}=1065.23 \\
\mathrm{~T}_{0}=9.90 \\
\mathrm{H}_{0} \text { Rejected }\end{array}$ \\
\hline
\end{tabular}

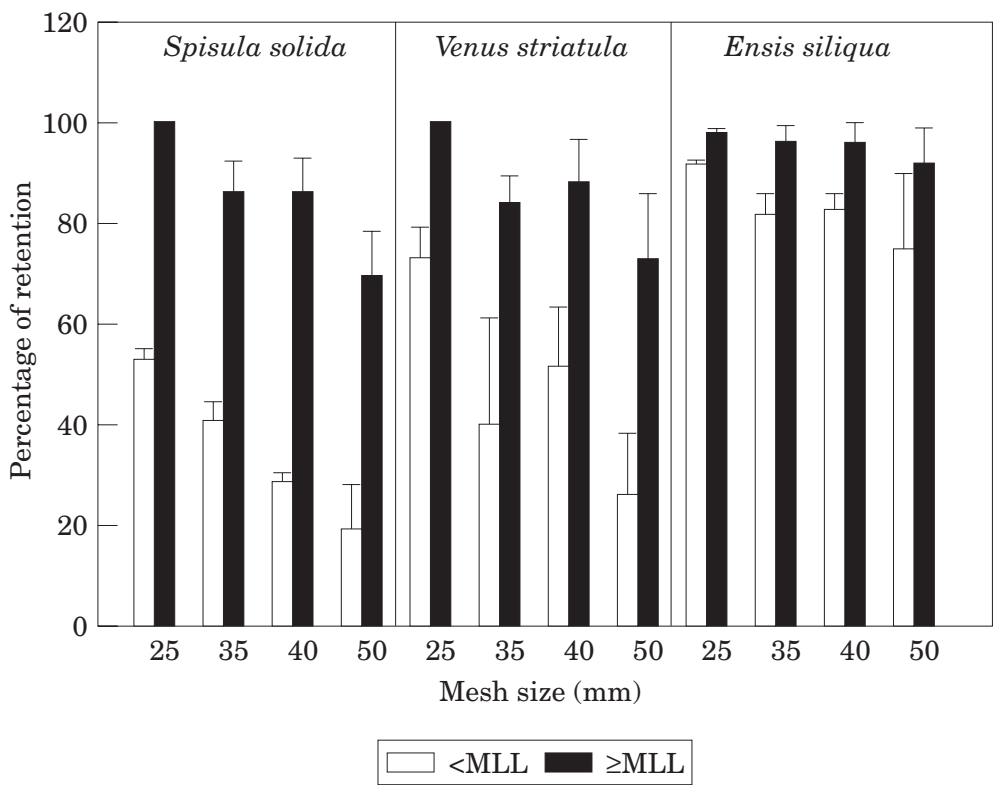

Figure 5. Percentage of retention of the individuals with lengths below and above the minimum legal landing length (MLL) for each mesh size and species. The error bars represent 2 standard deviations.

experiments were designed so that this factor would be constant. The duration of the tows was a constant 3 min. Of the other factors inherent to the dredge itself, tooth spacing and the mesh size were considered to be potentially the most important. Tooth spacing was analysed first. The present work showed that, with the dredge 
design used, the spacing of the teeth was of no importance. The tooth bar must act as a hoe. As a result of this bulldozing effect the Portuguese dredge has a high efficiency of capture (Gaspar, 1996). Although the effect of tooth spacing has been found to be significant in other studies (Baird and Gibson, 1956; Drinkwater, 1974; Nashimoto, 1984; Nashimoto et al., 1983), these authors recognized that the effect of tooth spacing on selectivity was of minor importance when compared to mesh size.

\section{Acknowledgements}

The authors would like to thank Dr Karim Erzini for reviewing the manuscript and Dr Michael Chadwick and two other anonymous referees whose suggestions greatly improved the manuscript. The authors also thank the staff of the Centro Regional de Investigação Pesqueira do Sul for collecting the samples, and the crew of "NI DONAX" for their skilful handling of the boat and fishing gears. The authors would also like to acknowledge the Junta Nacional de Investigação Cientifica e Tecnológica - Programa Ciência and Praxis XXI, which funded M. B. Gaspar.

\section{References}

Baird, R. H., and Gibson, F. A. 1956. Underwater observations on scallop (Pecten maximus L.) beds. Journal of the Marine Biological Association of the UK, 35: 555-562.

Bernard, D. R. 1981. Multivariate analysis as a means of comparing growth in fish. Canadian Journal of Fisheries and Aquatic Sciences, 38: 233-236.

Caddy, J. F. 1989. A perspective on the population dynamics and assessment of scallop fisheries, with reference to the sea scallop, Placopecten magellanicus Gmelin. In Marine invertebrate fisheries; their assessment and management, pp. 559589. Ed. by J. F. Caddy. John Wiley and Son Inc., Interscience, New York. 752pp.

Drinkwater, J. 1974. Scallop dredge selectivity experiments. ICES C.M. 1974/K:25, 5pp.
Gaspar, M. B. 1996. Bivalves do litoral oceânico algarvio. Aspectos da biologia, ecologia e da pescaria dos manancias de interesse económico: aplicação à gestão dos recursos. $\mathrm{PhD}$ thesis, Universidade do Algarve.

Gaspar, M. B., Richardson, C. A., and Monteiro, C. C. 1994. Annual shell banding, age, and effects of dredging on the shells of a population of the razor clam Ensis siliqua L., from Barrinha, south of Portugal. Journal of the Marine Biological Association of the UK, 74: 927-938.

Gaspar, M. B., Castro, M., and Monteiro, C. C. 1995. Age and growth rate of the clam Spisula solida L., from a site off Vilamoura, south Portugal, determined from acetate replicas of shell sections. Scientia Marina, 59 (Suppl. 1): 87-93.

Gaspar, M. B., and Monteiro, C. C. 1998. Indirect mortality caused to juveniles of Spisula solida due to deck exposure. Journal of the Marine Biological Association of the UK (In press).

Hanumara, R. C., and Hoeing, N. A. 1987. An empirical comparison of a fit of linear and non-linear models for seasonal growth in fish. Fisheries Research, 5: 359-381.

Monteiro, C. C. 1985. Prospecção preliminar dos bivalves de interesse comercial do litoral algarvio - àrea de sotavento. Relatórios Instituto Nacional de investigação das Pescas, Lisboa, 44: 110pp.

Morrison, D. F. 1976. Multivariate statistical methods. 2nd edition. New York, McGraw-Hill Book Company, 415pp.

Nashimoto, K. 1984. The selectivity of the sunary surf clam dredge. Bulletin of the Japanese Society of Scientific Fisheries Nissuishi, 50: 1145-1155.

Nashimoto, K., Miyazawa, H., and Hiraishi, T. 1983. The tooth selectivity of Japanese surf clam dredge. Bulletin of the Japanese Society of Scientific Fisheries Nissuishi, 49 (3): 379-385.

Paloheimo, J. E., and Cadima, E. 1964. On statistics of mesh selection. ICNAF Serial No 1394/Doc. No 98.

Ruano, F. L. 1997. Fisheries and farming of important marine bivalves in Portugal. In U.S. Dep. Commer., NOAA Tech. Rep. NMFS 129: 191-200.

SAS Institute Inc., 1989. SAS/STATS ${ }^{\circledR}$ User's guide, Version 6, Fourth Edition, Volume 2, Cary, NC. SAS Institute Inc. North Carolina, Cary, 846 pp.

Silva, A. A. B. 1893. Estado actual das pescas em Portugal. Ed Imprensa Nacional, Lisboa. 